\title{
Energy efficient urban districts: A multi-criteria application for selecting retrofit actions
}

\author{
Domenico Dirutigliano $^{1 *}$, Chiara Delmastro ${ }^{1}$, Sara Torabi Moghadam ${ }^{2}$ \\ ${ }^{1}$ Department of Energy, Politecnico di Torino, Corso Duca degli Abbruzzi 24, Turin 10129, Italy \\ ${ }^{2}$ Interuniversity Department of Regional and Urban Studies and Planning, Politecnico di Torino, \\ Viale Mattioli 39, Turin 10125, Italy
}

Email: domenico.dirutigliano@polito.it

\begin{abstract}
The definition of the new paradigms for transition strategies toward sustainable development and low-carbon cities is crucial, mainly, in the built environment sector which is the key driver of energy consumption and carbon emission. Starting from the energy characterization of the urban environment, the paper proposes a multi-criteria decision aiding model as a support tool for promoting the energy retrofitting of urban districts. The PROMETHEE methodology has been applied to a case study in the city of Torino for outranking five different proposed alternatives for buildings refurbishment that allows to achieve $20 \%$ energy saving. Three main phases characterize the study: $i$. analysis of the buildings stock and alternatives identification; ii. criteria definition and quantification; iii. model implementation and result discussion. The model fits well the purpose of the analysis and highlights that Multi Criteria Decision methods can provide relevant feedbacks and considerable help to building designers, planners and decision makers for ranking complex design energy options and select the most energy savings retrofitting scenario.
\end{abstract}

Keywords: Multi Criteria Analysis, Urban District, Energy Savings Scenarios, Building Stock, GIS.

\section{INTRODUCTION}

Buildings are responsible of $40 \%$ of energy consumption and $36 \%$ of $\mathrm{CO}_{2}$ emissions in the European Union [1]. An analysis shows that emission could be reduced by around $90 \%$ in this sector by 2050 [2]. Most of the building stock is characterized by low energy performances since it pre-dates the energy regulation, and in consequence, it is in compelling need of renovation, as shown in literature by [3] and [4]. Therefore, the definition of the proper retrofitting strategies toward low-carbon cities is crucial, mainly, in the built environment sector which is the key driver of energy consumption and carbon emission. Especially, considering the existing Italian building stock contest, it is evident the importance of building retrofit as remarked in [5]. Nevertheless, selecting among the multiple available retrofit solutions may result difficult for a decision maker. Indeed, Multi-Criteria Analysis (MCA) is a proper method that can help to generate better decisions when there is more than one criterion [6]. MCA methods are able to translate complicate problems in simpler ones in order to provide a complete image to the Decision-Makers (DMs)[7].

Particularly, the application of multi-criteria decision making to energy efficient urban planning has fascinated the decision makers' attention for a long time as shown in [8] and [9]. MCA helps to resolve the complex situation of energy management problems [10]. In other words, energy planning is a suitable field for MCA methods because it is subject to many sources of uncertainty, long time frames and capital-intensive investments along with featuring multiple Decision Makers (DMs). As a matter of fact, energy efficient urban districts involve the consideration of a wide range of incommensurable criteria [11]. The complexity in the planning of local energy systems is discussed in more detail in the work conducted by [12].

Since clearly different methods lead to various results, the choice of MCA method reflects on the DMs' targets. Hence, one of the most important factors in choosing MCA is to select an appropriate method that fulfils the aim of the analysis. Additionally, the method must provide the DMs all the required information, and it must be compatible with the available data. The method should be also understandable and easy to use [13]. In the literature, several classifications of MCA methods exist in order to determine the preference orders of alternatives. Regarding the sustainable energy decision-making, they can be divided into three main categories [14]:

(1) Elementary methods: these methods consist in nonpreference information methods without decision maker, and multi- attribute information methods with decision maker. (e.g. WSM, WPM);

(2) Methods in unique synthesizing criteria: these 
approaches convert the different criteria impacts into one criterion or attribute, which build the base for the comparison of the alternatives [15]. (e.g. AHP, TOPSIS, MAUT, MACBETH);

(3) Outranking methods: these methods construct and exploit of an outranking relation [16]. It is a binary relation $S$ defined on the group of alternative $A$. If the preferences of the DMs are identified, the quality of the evaluations of the alternatives and the nature of the problem under consideration are enough elements for affirming that the alternative $A_{i}$ is at least as good as the alternative $A_{k}$, for any pair of alternatives $\left(A_{i}, A_{k}\right) \in$ $A \times A: A_{i} S A_{k}$. Unlike to other MCA methods, the outranking methods have an important feature, which allows incomparability between alternatives. (e.g. ELECTRE, PROMETHEE, ORESTRE).

A more detailed studies regarding the theoretical foundations of the aforementioned methods can be found in [17], [18] and [19]. The present paper illustrates the application of PROMETHEE method to a case study. The goal is to outrank five different proposed alternatives for buildings refurbishment that allows to achieve $20 \%$ energy saving at district level. In section 2 the PROMETHEE method is described, while section 3 proposes a case study application. Section 4 and 5 are dedicated respectively to the discussion of results and conclusions. Section 6 describes the concluding remarks and future development.

\section{METHODOLOGY}

This section describes the fundamentals of the PROMETHEE method, chosen for outranking the alternatives proposed in this paper.

\subsection{PROMETHEE method}

As stated earlier, the PROMETHEE method (preference ranking organization method for enrichment evaluation) belongs to the outranking category, which has been developed by Brans et al. [20]. Moreover, it has been used broadly in the field of energy planning and its applications, such as [21].

The PROMETHEE method uses the partial aggregation and it is very useful in ranking a limited number of alternatives, considering conflicting criteria [22]. It is based on the pair-wise comparison, checking if one of two alternatives outrank the other or not. Two specific types of information are need in order to implement this method. They are the criteria weights and the decision-maker's preference function for comparing the contribution of the alternatives in terms of each separate criterion [23]. According to [23], three following steps are needed for the implementation of the method:

(1) The pair-wise comparison of the alternatives for each criterion, expressing the preference in the numerical way $[0,1]$. Where, $0=$ no preference or indifference; $1=$ strict preference. Generalized criterion (i.e. the function relating the difference in performance to preference) is should be defined by DMs.

(2) For each pair of alternatives, a and b, is needed to determine a multi-criteria preference index. This value is a weighted average of the corresponding preferences computed in step (1) for each criterion. The index
Preference (in the interval $[0,1]$ ) illustrates that the alternative $\mathrm{a}$ is preferred over $\mathrm{b}$ taking into account all criteria. The relative importance of each criterion is expressed by weighting factors, which is to be selected by DMs.

(3) Alternatives can be ranked according to "leaving flow" or "entering flow".

PROMETHEE methods consist of PROMETHEE II, the GAIA analysis (Graphical Analysis for Interactive Aid), PROMETHEE V (Optimization under constraints), the group decision support system PROMETHEE GDSS [24].

\subsection{Proposed PROMETHEE method}

This section presents the application of the PROMETHEE method through Excel worksheets developed by authors to evaluate different building district retrofitting solutions. This decision has been taken in order to test the efficacy of a simple method that can be used by all the urban actors from citizen to decision makers. The proposed methodology is divided in sequential steps as presented in Fig. 1.

Step 1 Problem definition: the first step is to structure the urban energy problems and goals. However, it is crucial to consider serval relative constraints in the given context (e.g. economic budget limitation, energy saving target, etc.)

Step 2 Data analysis: the data analysis phase is needed in order to create a supportive database for performing the next steps (e.g. criteria definition, alternative definition, etc.). The available data on which application is to be performed about the existing building stock has been collected and analysed. This step was performed through the GIS tool, which is able to manage and store big data regarding to building stock at the urban scale.

Step 3 Criteria Selection: the selection of criteria typically requires a profound overview of the literature [14]. The relevant literature-based criteria to assess the retrofit alternatives are mostly divided into technical, economic, environmental and social aspects [25]. However, relative projects and national standards should be taken into account in the selection the criteria. Moreover, it is essential to consider the particularities and the objectives of the given problem. Especially, the number of the selected criteria in a decision process need to be adequate and non-redundant [26]. Once in this step, a set of criteria was selected trough the relevant literature [14], a group of different stakeholders involved in the retrofitting project has been formed (i.e. urban planner, urban energy expert and built environment expert) in order to finalize the final set of criteria based on the stakeholders' preferences and knowledge.

Step 4 Criteria Weights Assignment: regarding PROMETHEE methods, each criterion should have assigned an importance by the DMs through a weight. However, PROMETHEE methods do not have any specific technique for determining the weights of $w_{j}$ the criteria. The weight assignment of the criteria is significantly important since it could change the decisional results. According to [14], two general methods for weighting the criteria exist (i) "Equal weights method", where the weights of criteria are evaluated as " $w_{i}=\frac{1}{n}, i=1,2, \ldots, n$ "; and (ii) "Rank-order weights method" (i.e. Subjective and Objective and Combination), where criteria weigh takes into account the relative importance among criteria as " $w_{1} \geq w_{2} \geq \cdots \geq w_{n} \geq$ $0, \sum_{i=1}^{n} w_{i}=1$ ". In this study, authors started adopting the 
"equal weights method" and then applied the "Rank-order weights method" in order to test the robustness of the result.

Step 5 Definition of Alternatives: this step consists in evaluating to which amount each option's combination is contributing to energy savings with respect to the different building types. Once the building stock is characterized and the decisional criteria are defined, the analysts (experts in the field) should define different retrofitting alternatives. The retrofitting solutions will take into account will concern the building envelope (e.g., windows replacement, insulation of the opaque envelope), the increase of the heating system efficiency (e.g., boiler replacement, control system improvement) or the use of renewable energy resources (e.g. solar thermal plant or solar photovoltaic (PV)) [27]. This step can also be performed with a participative approach.

Step 6 Construction of the evaluation matrix: in this step, the evaluation matrix was built in order to analyse the alternatives through the use of PROMETHEE. Multiple decision matrix for sustainable energy problems typically consists in $m$ alternatives evaluated on $n$ criteria and their relative weights $(w)$ [14], [28].

Step 7 Method Application: in this step, the application of the PROMETHEE method is applies to analyse and compare the retrofitting alternatives.

Step 8 Result Ranking: this step indeed explores and compares the impact of different energetic retrofitting alternatives over a specific time-horizon. The comparison is based on the net flow Phi value, which indicates the result of all the pair-wise comparisons of the alternatives. The net flow Phi is calculated as the difference between the positive and negative outranking flows. The best alternatives are therefore the ones characterized by higher net flow Phi values.

Step 9 Sensitivity Analysis: in this step, the effect of weight and threshold changes on the results are analysed.

\begin{tabular}{|c|}
\hline Problem Definition \\
\hline Data Analyses \\
\hline Criteria Selection \\
\hline Criteria Weights Assignment \\
\hline Definition of Alternatives \\
\hline Construction of the evaluation matrix \\
\hline Method application \\
\hline Result Ranking PROMETHEE \\
\hline Sensitivity Analysis \\
\hline
\end{tabular}

Figure 1. Conceptual scheme of proposed methodology

\section{APPLICATION OF THE PROMETHEE METHOD TO ENERGY PLANNING IN TURIN}

\subsection{Problem definition}

This section illustrates the structure of the research problem definition. This assessment exercise is based on a focus group to develop the criteria, alternatives and weights. The authors undertake the role of decision-makers since the aim of the work is academic. It is hypothesized different energy development scenarios finalized to a reduction of the energy consumption for about $20 \%$ for the district starting from the data collection.

In this study, it is assumed that the Municipality can invest a maximum of $17 \mathrm{M} €$ to finance the energy renovation of the residential building stock, improving simultaneously the life quality of inhabitants. The available budget is intended as a financial incentive up to $60 \%$ of initial investment cost while the citizens shall bear the remaining costs $(40 \%$ of investments). The decision of covering $60 \%$ of initial capital cost has been taken by authors with the aim to test a new energy policy in substitution to tax detraction over 10 years (currently equal to $65 \%$ )

The research problem is defined as: "Which retrofitting alternatives and strategies are best applied to generate both economic and socio-environmental benefits?".

The decisional problem is to choose among different alternatives that include different retrofitting technologies, applying on a number of buildings with the aim of reducing energy consumption of about $20 \%$. This objective derived from the European strategies towards the achievements of 2020 targets, which is a great challenge nowadays in order to refurbish of existing buildings [1].

\subsection{The study area}

The study area involves 198 buildings sited in the "District 3 " of the city of Turin, Italy. Turin is in the temperate continental climatic zone $\left(2617 \mathrm{HDD}\right.$ at $20^{\circ} \mathrm{C}$ ) and it is characterized by 10 districts and about 40,000 residential buildings (most of them built before the '80s) and 3839 census sections. The building stock of the district (Fig. 2.) has been characterized in previous works thanks to a GIS platform and simulation analyses [29]. Building volumes are between 3,000 and $30,000 \mathrm{~m}^{3}$ while space heating energy
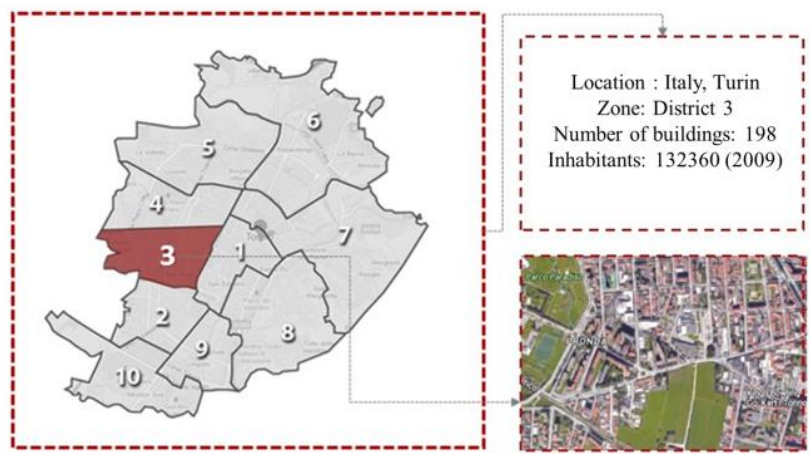

consumption is between 55 and $240 \mathrm{kWh} / \mathrm{m}^{2} / \mathrm{yr}$.

Figure 2. Case study district 3, Turin, Italy

\subsection{Data preparation and analysis, identification of alternatives}

Table 1. Buildings types sited in the relevant district*

\begin{tabular}{cccc}
\hline $\begin{array}{c}\text { Building } \\
\text { Type }\end{array}$ & Family type & $\begin{array}{c}\text { Year of } \\
\text { Construction }\end{array}$ & $\begin{array}{c}\text { Number of } \\
\text { building }\end{array}$ \\
\hline Type 1 & MF & before 1980 & 132 \\
\hline Type 2 & SF & before 1980 & 50 \\
\hline Type 3 & MF & 1981 to 2005 & 8 \\
\hline Type 4 & SF & 1981 to 2005 & 6 \\
\hline
\end{tabular}




\section{Type 5} MF after 2006

$* \mathrm{MF}=$ multi-family, $\mathrm{SF}=$ single family

The sample area is constituted by 198 buildings. The sample buildings have been classified into five building types as in Table 1.

To match the total goal of $20 \%$ energy savings, a mix of different options has been considered:

- Standard envelope refurbishment of buildings

(Package 1 for MF and Package 2 for SF);

- The installation of thermostatic valves;

- The installation of electric heat pumps;

- The installation of mechanical ventilation;

- The installation of PV panels.

The alternatives should be characterized by different combinations of the proposed options in order achieve the target. For this research, five options' combinations have been identified and proposed (Table 2).

Table 2. Packages combination

\begin{tabular}{|c|c|}
\hline Packages & Strategies Description \\
\hline 1 & standard envelope renovation \\
\hline 2 & $\begin{array}{l}\text { standard envelope renovation coupled with the } \\
\text { installation of thermostatic valves }\end{array}$ \\
\hline 3 & $\begin{array}{c}\text { standard envelope renovation coupled with } \\
\text { thermostatic valves and with heat pumps' } \\
\text { installation }\end{array}$ \\
\hline 4 & $\begin{array}{l}\text { standard envelope renovation and the installation of } \\
\text { mechanical ventilation }\end{array}$ \\
\hline 5 & $\begin{array}{l}\text { installation of heat pumps together with PV } \\
\text { systems }\end{array}$ \\
\hline
\end{tabular}

Table 3. Alternative scenarios

\begin{tabular}{|c|c|c|}
\hline \multicolumn{2}{|c|}{$\begin{array}{l}\text { Alternative } \\
\text { energy saving }\end{array}$} & $\begin{array}{c}\text { Development of building refurbishment } \\
\text { alternatives }\end{array}$ \\
\hline $\begin{array}{c}\text { A } \\
1\end{array}$ & Envelope & $\begin{array}{c}\text { Package } 1 \text { Standard applied to } 28 \text { Building } \\
\text { Type } 1 \text { and } 8 \text { Building Type } 3+ \\
\text { Package } 2 \text { Standard applied to } 15 \text { Building } \\
\text { Type } 2 \text { and } 6 \text { Building Type } 4\end{array}$ \\
\hline $\begin{array}{l}\text { A } \\
2\end{array}$ & $\begin{array}{l}\text { Envelope+ } \\
\text { Control } \\
\text { system }\end{array}$ & $\begin{array}{c}\text { Package } 1 \text { Standard applied to } 24 \text { Building } \\
\text { Type } 1 \text { and } 8 \text { Building Type } 3+ \\
\text { Package } 2 \text { Standard applied to } 14 \text { Building } \\
\text { Type } 2 \text { and } 6 \text { Building Type } 4+ \\
\text { thermostatic valves installed into } 54 \text { buildings } \\
\text { including Building Type } 5\end{array}$ \\
\hline $\begin{array}{c}\text { A } \\
3\end{array}$ & $\begin{array}{l}\text { Envelope+ } \\
\text { Control } \\
\text { system }+ \\
\text { Plant } \\
\text { system }\end{array}$ & $\begin{array}{c}\text { Package } 1 \text { Standard applied to } 19 \text { Building } \\
\text { Type } 1 \text { and } 4 \text { Building Type } 3+ \\
\text { Package } 2 \text { Standard applied to } 15 \text { Building } \\
\text { Type } 2 \text { and } 6 \text { Building Type } 4+ \\
\text { thermostatic valves installed into } 46 \text { buildings } \\
\text { including Building Type } 5+ \\
\text { Heat Pumps installed into } 19 \text { Building Type } 1 \\
\text { and } 4 \text { Building Type } 3\end{array}$ \\
\hline $\begin{array}{c}\mathrm{A} \\
4\end{array}$ & $\begin{array}{l}\text { Envelope+ } \\
\text { Plant } \\
\text { system }\end{array}$ & $\begin{array}{c}\text { Package } 1 \text { Standard applied to } 18 \text { Building } \\
\text { Type } 1 \text { and } 4 \text { Building Type } 3+ \\
\text { Package } 2 \text { Standard applied to } 14 \text { Building } \\
\text { Type } 2 \text { and } 6 \text { Building Type } 4+ \\
\text { mechanical ventilation installed into } 44 \\
\text { buildings including Building Type } 5 \\
\end{array}$ \\
\hline $\begin{array}{c}\text { A } \\
5\end{array}$ & $\begin{array}{c}\text { Plant } \\
\text { system } \\
+ \text { Renewab } \\
\text { le sources }\end{array}$ & $\begin{array}{c}\text { HP + PV installed into } 32 \text { Building Type } 1 \\
\text { and } 8 \text { Building Type } 3+ \\
18 \text { Building Type } 2 \text { and } 6 \text { Building Type } 4+2 \\
\text { Building Type } 5\end{array}$ \\
\hline
\end{tabular}

The first step consists in evaluating to which amount each options combination is contributing to energy savings with respect to the different building types. The energy evaluations are referred to [29] and to the TABULA project [3]. Considering the volumes' distribution, the alternatives are thus described in Table 3 and Fig. 3.

As can be observed, it is not necessary to perform deep retrofit on the whole buildings. Accordingly, to the options' combinations, the number of involved buildings in renovation works have changed from a minimum of 57 to a maximum of 113 . In this case, five progressive scenarios have been supposed by researchers and experts starting from the envelope requalification to the exploitation of the renewable sources and comparing them (Table 3 ).

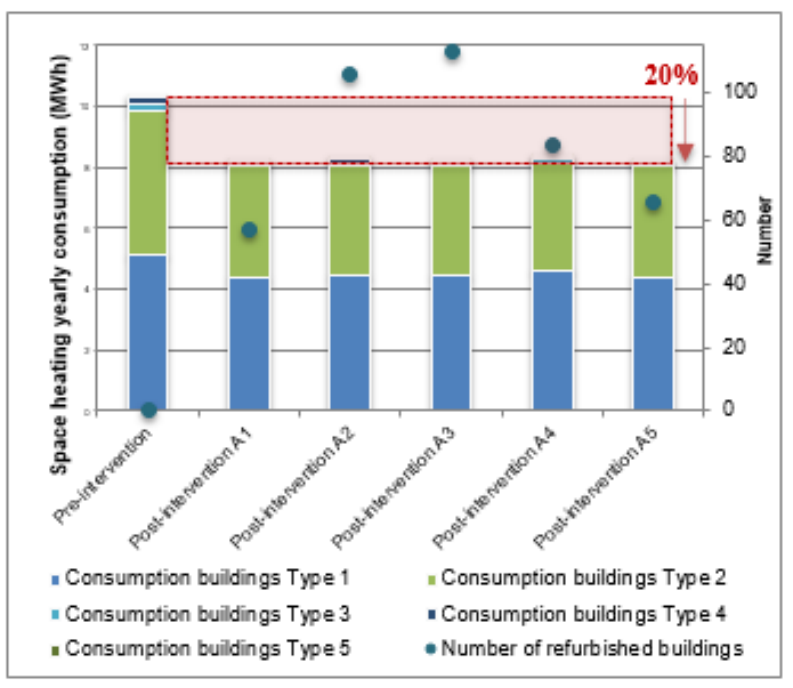

Figure 3. Energy savings and number of buildings

\subsection{Identification of criteria}

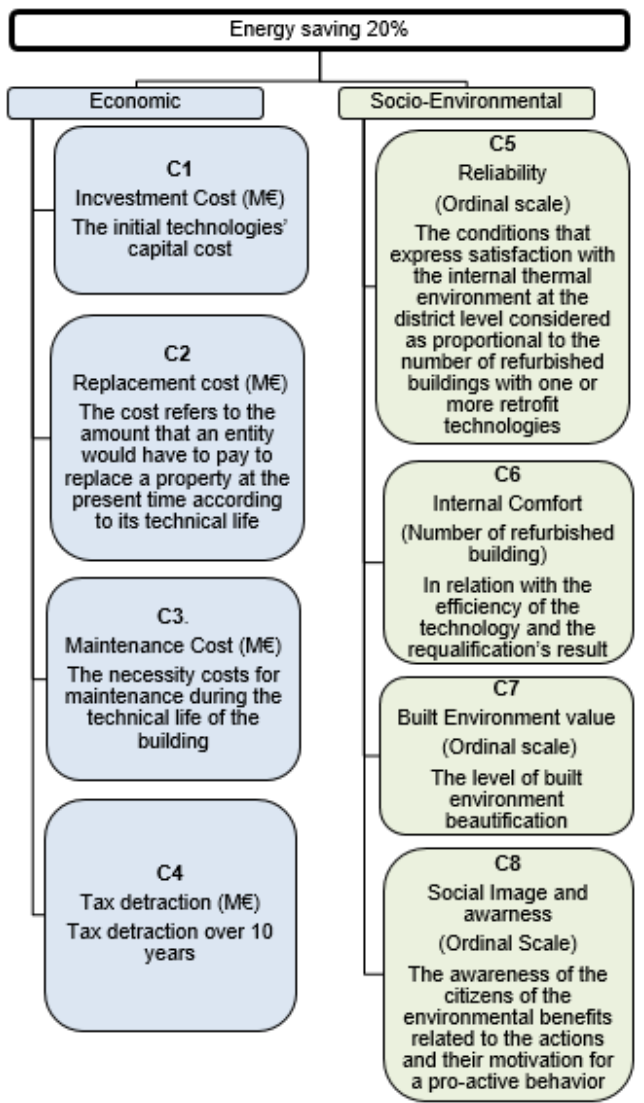


Figure 4. Criteria identification

Table 4. Reliability ordinal scale

\begin{tabular}{|c|c|c|}
\hline Num. & Reliability & Description \\
\hline 1 & failure & $\begin{array}{l}\text { low efficiency of the technology } \\
\text { (lower than } 80 \% \text { ) and low probability } \\
\text { of success of the measure }(>70 \% \text { ) }\end{array}$ \\
\hline 2 & $\begin{array}{l}\text { low } \\
\text { probability } \\
\text { of success }\end{array}$ & $\begin{array}{l}\text { low efficiency of the technology } \\
\text { (lower than } 80 \% \text { ) or low probability } \\
\text { of success of the measure }(>70 \%)\end{array}$ \\
\hline 3 & $\begin{array}{l}\text { medium } \\
\text { probability } \\
\text { of success }\end{array}$ & $\begin{array}{l}\text { high efficiency of the technology } \\
\text { (higher than } 80 \% \text { ) or high probability of } \\
\text { success of the measure }(>80 \%)\end{array}$ \\
\hline 4 & $\begin{array}{l}\text { high } \\
\text { probability } \\
\text { of success }\end{array}$ & $\begin{array}{l}\text { high efficiency of the technology } \\
\text { (higher than } 90 \% \text { ) and high probability } \\
\text { of success of the measure }(>80 \% \text { ) }\end{array}$ \\
\hline 5 & success & $\begin{array}{l}\text { high efficiency of the technology } \\
\text { (higher than 1) and high probability of } \\
\text { success of the measure }(>90 \%)\end{array}$ \\
\hline
\end{tabular}

Table 5. Social Image and awareness ordinal scale

\begin{tabular}{c|c|c}
\hline Num. & $\begin{array}{c}\text { Social image } \\
\text { and } \\
\text { awareness }\end{array}$ & Description \\
\hline 1 & $\begin{array}{c}\text { unacceptable } \\
\text { to people }\end{array}$ & $\begin{array}{c}\text { the solution is not in the cultural tradition } \\
\text { of people and they are not aware about } \\
\text { the benefits }\end{array}$ \\
\hline 2 & $\begin{array}{c}\text { low } \\
\text { acceptability }\end{array}$ & $\begin{array}{c}\text { the solution is not diffused in the area } \\
\text { and people have low awareness about } \\
\text { its benefits }\end{array}$ \\
\hline 4 & $\begin{array}{c}\text { medium } \\
\text { acceptability } \\
\text { high } \\
\text { acceptability }\end{array}$ & $\begin{array}{c}\text { the solution normally adopted in the } \\
\text { area and the related benefits are known }\end{array}$ \\
\hline 5 & $\begin{array}{c}\text { extremely } \\
\text { high } \\
\text { acceptability }\end{array}$ & $\begin{array}{c}\text { built environment beautification } \\
\text { beautification }\end{array}$ \\
\hline
\end{tabular}

Table 6. Built environment ordinal scale

\begin{tabular}{c|c|c}
\hline Num. & Built environment value & Description \\
\hline 1 & $\begin{array}{c}\text { unacceptable built } \\
\text { environment }\end{array}$ & $\begin{array}{c}\text { degraded built } \\
\text { environment }\end{array}$ \\
\hline 2 & lower built environment & $\begin{array}{c}\text { worsened built } \\
\text { environment }\end{array}$ \\
\hline 3 & medium built environment & $\begin{array}{c}\text { the built environment } \\
\text { doesn't change }\end{array}$ \\
\hline 4 & $\begin{array}{c}\text { improved built } \\
\text { environment } \\
\text { beautification }\end{array}$ \\
\hline 5 & $\begin{array}{c}\text { high built environment } \\
\text { improvement }\end{array}$ & $\begin{array}{c}\text { built environment } \\
\text { consistent } \\
\text { beautification }\end{array}$ \\
\hline
\end{tabular}

First, the criteria and the alternatives were defined based on literature, and then, discussed during the focus group, involving three different stakeholders: an urban energy planner, an urban energy engineer and a built environment expert. Moreover, as a consequence of the focus group discussion, eight criteria have been defined with the aim at structuring the model. The criteria are divided into Economic and Socio-Environmental indicators both quantitative and qualitative as shown in Fig. 4. Criteria are divided into:

- Quantitative Criteria: Investment costs, Maintenance cost,

Tax Detraction, Replacement Cost and Internal Comfort; (discussed in section 3.2)

- Qualitative Criteria: Built Environment value, Reliability and Social image and awareness. Figure 4 shows the criteria and their descriptions. For the assessment of the qualitative criteria values, ordinal scales have been considered (Table 4. 5. 6.).

The tax detraction criterion is intended as economic savings for the Municipality. In fact, the latter pays the $60 \%$ of initial investment to citizens instead of providing the tax detraction in the next 10 years.

\subsection{Performance matrix}

To apply the PROMETHEE method, the model parameters (i.e. indifference $(q)$ and/or preference (p) thresholds) related to each criterion need to be defined. A certain level of uncertainties affects some evaluations; thus, the indifference and preference thresholds are presented to control the impact of a limited precision. The values associated to each criterion related to the alternatives are proposed in Table 7 .

Table 7. Performance matrix

\begin{tabular}{|c|c|c|c|c|c|c|c|c|}
\hline & \multicolumn{4}{|c|}{ Economic } & \multicolumn{4}{|c|}{ Socio_Environmental } \\
\hline Criteria & $\mathrm{C} 1$ & $\mathrm{C} 2$ & $\mathrm{C} 3$ & $\mathrm{C} 4$ & $\mathrm{C} 5$ & C6 & $\mathrm{C} 7$ & $\mathrm{C} 8$ \\
\hline $\begin{array}{c}\text { Measurin } \\
\text { g units }\end{array}$ & $(\mathrm{M} €)$ & $(\mathrm{M} €)$ & $(\mathrm{M} €)$ & $(\mathrm{M} €)$ & $\begin{array}{l}\text { (Ordina } \\
1 \text { scale })\end{array}$ & $\begin{array}{c}\text { (Number } \\
\text { of } \\
\text { refurbishe } \\
\mathrm{d} \\
\text { buildings) }\end{array}$ & $\begin{array}{l}\text { (Ordina } \\
1 \text { scale) }\end{array}$ & $\begin{array}{l}\text { (Ordina } \\
1 \text { scale) }\end{array}$ \\
\hline Weights & $\begin{array}{c}0.12 \\
5 \\
\end{array}$ & $\begin{array}{c}0.12 \\
5\end{array}$ & $\begin{array}{c}0.12 \\
5\end{array}$ & $\begin{array}{c}0.12 \\
5\end{array}$ & 0.125 & 0.125 & 0.125 & 0.125 \\
\hline $\begin{array}{c}\text { Min } \\
\text { Value }\end{array}$ & 3,37 & 1,73 & 1,24 & 0,3 & 2 & 57 & 1 & 1 \\
\hline $\begin{array}{c}\text { Max } \\
\text { Value }\end{array}$ & 10,1 & 3 & 3,7 & 3,3 & 5 & 113 & 5 & 5 \\
\hline $\operatorname{Max} \Delta$ & 6,73 & 1,27 & 2,46 & 3 & 3 & 56 & 4 & 4 \\
\hline $\operatorname{Min} \Delta$ & 0,3 & 0,07 & 0,1 & 0,1 & 1 & 7 & 1 & 1 \\
\hline A 1 & 8,1 & 1,8 & 3,0 & 3,3 & 3 & 57 & 5 & 4 \\
\hline A 2 & 7,4 & 2,5 & 2,7 & 3,1 & 4 & 106 & 4 & 5 \\
\hline A 3 & 7,1 & 2,8 & 2,6 & 2,6 & 5 & 113 & 3 & 2 \\
\hline A 4 & 10,1 & 3,0 & 3,7 & 2,5 & 2 & 84 & 2 & 1 \\
\hline A5 & 3,37 & 1,73 & 1,24 & 0,3 & 2 & 66 & 1 & 3 \\
\hline
\end{tabular}

Table 8. Thresholds selection

\begin{tabular}{ccc}
\hline & Indifference thresholds (q) & $\begin{array}{c}\text { Preference thresholds } \\
(\mathrm{p})\end{array}$ \\
\hline $\mathrm{C} 1$ & 0,3 & 0,6 \\
\hline $\mathrm{C} 2$ & 0,07 & 0,14 \\
\hline $\mathrm{C} 3$ & 0,1 & 0,2 \\
\hline $\mathrm{C} 4$ & 0,1 & 0,5 \\
\hline $\mathrm{C} 5$ & - & - \\
\hline $\mathrm{C} 6$ & 7 & 25 \\
\hline $\mathrm{C} 7$ & - & - \\
\hline $\mathrm{C} 8$ & - & - \\
\hline
\end{tabular}

As a first attempt (Baseline), the weight associated to each of the $n$ criteria has been considered equal to $1 / n$ "Equal weights method". The indifference value (q) associated to each of the $n$ criteria has been set equal to the minimum values difference. In the Baseline, the preference value (p) of 
each criterion has been assumed as double of q (Table 8).

\section{APPLICATION OF METHOD AND SENSITIVITY ANALYSIS}

\subsection{Main results}

Once the baseline model has been implemented in the PROMETHEE, the tool provides the result in the form of net flow Phi ranking. It allows identifying the strengths and weaknesses of the problem's criteria and thresholds.

In Fig. 5 the result of the baseline model is showed.

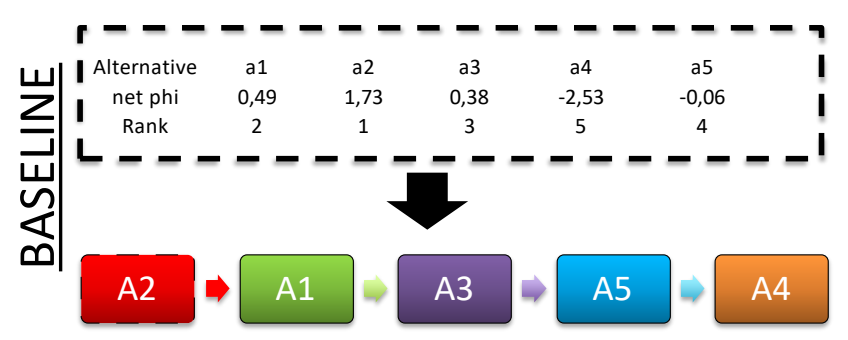

Figure 5. Baseline results

As can be observed in Fig. 5, the A2 Alternative is characterized by the highest net flow Phi value, and it is therefore identified as the best alternative. Alternatives A1 and A3 have net flow Phi values significantly lower compared to A2, but with closer values among themselves. Alternatives A5 and A4 have the lowest values of net flow Phi, in particular A4 that is the worst alternative. A sensitivity analysis can be performed in order to visualize the robustness of the model. Therefore, different weights and threshold values have been changed with respect to the Baseline scenario. Five mains "Changes" have been assumed by the focus group into the sensitivity analysis (Table 9). In all the scenarios, the indifferences thresholds have not been changed.

In "Change 1", "Change 3" and "Change 5" new weights with respect to Baseline of the criteria have been proposed. They have been indicated by considering the different perspectives of the experts involved in the focus group. In all the changes, the sum of the weights relative to the economic and socio-environmental criteria have been maintained constant $(0.5$ for economic criteria and 0.5 for socioenvironmental criteria). However, among the weight Changes, the economic criteria have constant weights while the socio-environmental ones vary. Taking into account the relevance of Investment Cost, a higher weight has been assigned to this criterion. During the discussion of the focus group, any of the Socio-economic criteria prevailed. Therefore, little weight variations $(0.025)$ have been proposed in the Changes respectively to the more technical criteria (Reliability and Internal Comfort) and to the more social oriented criteria (Built Environment Value and Social Image and Awareness). Moreover, in "Change 2", "Change 3 " and "Change 5", new preference thresholds are proposed in order to increase the Investment preference and the Internal Comfort preference. This choice is justified by the possible intention of the Municipality in investing more for achieving a higher comfort level for citizens. All the preference and weight combinations are shown in Table 9.

Table 9. Changes for the sensitivity analysis

\begin{tabular}{|c|c|c|c|c|c|c|c|c|c|}
\hline & & Inv. & Main. & Tax d. & Rep. & Built. & Rel. & Int. Com. & Soc. Im. \\
\hline \multirow{3}{*}{ Baseline } & Weight & - & - & + & - & + & + & + & + \\
\hline & p & $\begin{array}{c}\text { INV } \\
\text { COST }\end{array}$ & $\begin{array}{l}\text { MAIN } \\
\text { COST }\end{array}$ & $\begin{array}{c}\text { TAX } \\
\text { DETRA }\end{array}$ & $\begin{array}{c}\text { REP } \\
\text { COST }\end{array}$ & B ENV & RELIAB & $\begin{array}{c}\text { COMFO } \\
\text { RT }\end{array}$ & soc \\
\hline & q & c1 & c3 & c4 & c2 & c7 & c5 & c6 & c8 \\
\hline \multirow{3}{*}{$\begin{array}{c}\text { Change } 1 \\
\text { (Baseline }+ \\
\text { new weights) }\end{array}$} & Weight & 0,17 & 0,11 & 0,11 & 0,11 & 0,15 & 0,10 & 0,10 & 0,15 \\
\hline & $p$ & 0,60 & 0,20 & 0,20 & 0,14 & 2,00 & 2,00 & 25,00 & 2,00 \\
\hline & q & 0,30 & 0,10 & 0,10 & 0,07 & 2,00 & 2,00 & 7,00 & 2,00 \\
\hline \multirow{3}{*}{$\begin{array}{c}\text { Change } 2 \\
\text { (Baseline + } \\
\text { New P } \\
\text { thresholds) }\end{array}$} & Weight & 0.125 & 0.125 & 0.125 & 0.125 & 0.125 & 0.125 & 0.125 & 0.125 \\
\hline & $p$ & 4,50 & 0,20 & 0,20 & 0,14 & 2,00 & 2,00 & 40,00 & 2,00 \\
\hline & q & 0,30 & 0,10 & 0,10 & 0,07 & 2,00 & 2,00 & 7,00 & 2,00 \\
\hline \multirow{3}{*}{$\begin{array}{c}\text { Change } 3 \\
\text { (Change1 + } \\
\text { New P } \\
\text { thresholds) }\end{array}$} & Weight & 0,17 & 0,11 & 0,11 & 0,11 & 0,15 & 0,10 & 0,10 & 0,15 \\
\hline & $p$ & 4,50 & 0,20 & 0,20 & 0,14 & 2,00 & 2,00 & 40,00 & 2,00 \\
\hline & $q$ & 0,30 & 0,10 & 0,10 & 0,07 & 2,00 & 2,00 & 7,00 & 2,00 \\
\hline \multirow{3}{*}{$\begin{array}{c}\text { Change } 4 \\
\text { (Baseline + } \\
\text { new socio- } \\
\text { environmental } \\
\text { weights) }\end{array}$} & Weight & 0,17 & 0,11 & 0,11 & 0,11 & 0,10 & 0,15 & 0,15 & 0,10 \\
\hline & $p$ & 0,60 & 0,20 & 0,20 & 0,14 & 2,00 & 2,00 & 25,00 & 2,00 \\
\hline & $q$ & 0,30 & 0,10 & 0,10 & 0,07 & 2,00 & 2,00 & 7,00 & 2,00 \\
\hline \multirow{3}{*}{$\begin{array}{c}\text { Change } 5 \\
\text { (Change 2+ } \\
\text { new socio- } \\
\text { nvironmental } \\
\text { weights) }\end{array}$} & Weight & 0,17 & 0,11 & 0,11 & 0,11 & 0,10 & 0,15 & 0,15 & 0,10 \\
\hline & $p$ & 4,50 & 0,20 & 0,20 & 0,14 & 2,00 & 2,00 & 40,00 & 2,00 \\
\hline & q & 0,30 & 0,10 & 0,10 & 0,07 & 2,00 & 2,00 & 7,00 & 2,00 \\
\hline
\end{tabular}

New Weights 1

Baseline Weights

New Weights 2

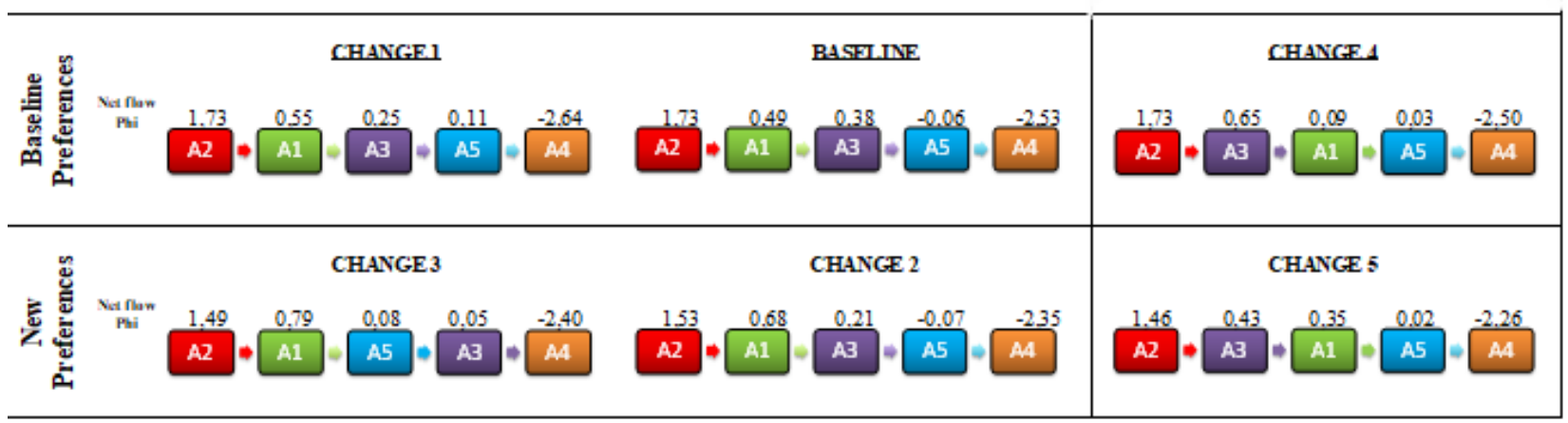

Figure 6. Results

\subsection{Outranking results}

From the model runs, by changing $\mathrm{p}$ and $\mathrm{q}$ thresholds as well as weights, the best alternative is always represented by A2 (coating + thermostatic valves), as it is shown in Fig. 6. It allows raising a significant comfort improvement, it has acceptable costs and does not have a relevant built environment impact. Moreover, it is a well-known solution with high market availability. Instead, A4 (coating + mechanical ventilation) is always the worst alternative since 
the cost of the technology is quite elevated and it is characterized by extremely low socio-environmental performances.

"Baseline", "Change 1" and "Change 2" present the same outranking of alternatives, where A2 is followed by A1 (coating), A3 (coating + thermostatic valves + heat pumps), A5 (PV panels + heat pumps) and A4. In these three Changes, the rank position is not affected by the sensitivity analysis even if net flow Phi values vary for every Changes. A1 has best performances concerning the built environment and the social image, while A3 has lower costs and higher comfort improvements. Instead, A5 can achieve the energy reduction goal at a lower price compared to all the other options, even if it has worst socio-environmental performances. A3 and A1 have very close values of net flow Phi.

"Change 4" and "Change 5" show the same outranking, where the second position is reached by A3 instead of A1. The proposed change of weights leads option A3 to be preferred to A1 since both Internal Comfort and Reliability of A3 are considerably higher compared to A1. The ranking of "Change 3 " is different from previous results because the third position is covered by A5. This alternative has the lowest investment cost, whose role is amplified by a higher weight. Furthermore, the changed preference for Internal Comfort decreases the difference (net flow Phi) between A5 and $\mathrm{A} 3$.

\section{DISCUSSION}

The paper proposes the analysis of different requalification scenarios through the application of multi-criteria analysis. The aim is to perform evaluations involving not only energy and environmental considerations, but also socio-economic ones. In this paper, the lesson learnt approach is applied to an exercise at the academic levels. This exercise has been developed by the authors in the role of decision-makers.

Typically, building energy efficiency interventions are chosen by taking into consideration the energy performance improvements and their associated costs in according to the cost-optimal method introduced by Directive 2010/31/EU.

By using the proposed multi- criteria approach, relevant feedbacks can be provided to building designers and planners for ranking complex design energy options in according also to the social needs. The results show that the model is robust since a single best alternative (A2, envelope measures + control system) and only one worse alternative (A4, envelope measures + mechanical ventilation) are identified.

\section{CONCLUDING REMARKS AND FUTURE DEVELOPMENT}

This work demonstrates the suitability of applying the PROMETHEE method for the outranking analysis of different alternatives to improve energy efficiency in buildings at the district level.

The concluding remarks derived from this long process are outlined below.

- The alternative scenarios should be characterized by different technological retrofitting choices to a different number of buildings in order to avoid a progressive evolution of alternatives with obvious results.
- It is suggested to consider a unambiguous odd ordinal scale for the definition of qualitative criteria performances in order to identify a neutral value.

- A sequence of changes (scenarios) in model parameters should be done in order to understand which are the model limitations and to restructure the model itself.

- The choice of thresholds is a very critical step of the MCA. The stakeholders' experiences and knowledge can help to reasonably choose these values.

- The weight values should be varied accordingly to the focus group preferences and not be defined a priori.

- The distribution of the importance of coefficients between the criteria (set of weights) should not be substantially diverse in different scenarios.

For a possible future development of a real project, the following modifications in the proposed model are suggested.

- Improving the actual criteria and evaluations procedures according to the local conditions.

- The weights should emerge from a broader number of stakeholders with different background.

- Unequal distributions of qualitative and quantitative criteria may be tested.

- Criteria need to be unambiguously defined by referring to actual laws, standards' targets, previous literature and stakeholders' experiences. For example, the values related to the useful life of technologies should derive from constructors' certificates. The lack of reliability of data makes difficult to assess with high precision the value of the specific criterion; such uncertainties may have an impact on the inclusion status of the criterion in the analysis.

One possible development of this paper is to replicate this application of the method expanding both the number of buildings and the types of interventions. A generalization of this exercise is to generate a support decision maker's tools that can play an essential role for a sustainable and effective land governance. The instrument will help decision makers to select the best energy saving alternative to increase the sustainability of the whole district. This can lead to explore a range of possible future retrofitting scenarios for assisting urban planners, policy makers and built environment stakeholders in their efforts to plan, design and manage low carbon cities. Another development is to introduce additional criteria such as the economic benefits from the production of energy and the awareness campaigns to end users in order to expand the meaning and validity of this exercise.

The model fits well the purpose of the analysis and highlights that MCDA methods can provide relevant feedbacks to building designers and planners for ranking complex design energy options.

\section{ACKNOWLEDGMENT}

The presented work has been inspired by an exercise of the course "Decision aid methods". The authors modified the methodology and extended the exercise. The authors therefore aim to thank Professor Maria Franca Norese.

\section{REFERENCES}

[1] Directive 2010/31/EU of the European Parliament and of the Council of 19 May 2010 on the energy 
performance of buildings (2010). Official Journal of the European Union.

[2] A Roadmap for moving to a competitive low carbon economy in 2050, Communication from the commission to the European parliament, the council, the European economic and social committee and the committee of the regions. (2011). Brussels, Belgium.

[3] Ballarini I., Corgnati S.P., Corrado V. (2014). Use of reference buildings to assess the energy saving potentials of the residential building stock: The experience of TABULA project, Energy Policy, Vol. 68, pp. 273-284. DOI: 10.1016/i.enpol.2014.01.027

[4] Loga T., Stein B., Diefenbach N. (2016). TABULA building typologies in 20 European countries? Making energy-related features of residential building stocks comparable, Energy and Buildings, Vol. 132, pp. 4-12. DOI: $10.1016 /$ i.enbuild.2016.06.094

[5] Delmastro C., Mutani G., Perassi S. (2016). In use monitoring of public buildings. case study in north Italy, International Journal of Heat and Technology, Vol. 34, No. 2, pp. S266-S276. DOI: 10.18280/ijht.34S212

[6] Bogetoft P., Pruzan P. (1997). Planning with Multiple Criteria: Investigation, Communication and Choice, (2nd edition). Copenhagen Business School Press, Copenhagen, Hardbound, pp. 368.

[7] Dodgson J., Spackman M., Pearman A., Phillips L. (2001). DTLR multi-criteria analysis manual, UK dept. for transport, local government and the regions. from

http://www.communities.gov.uk/pub/252/Multicriteria analysismanualPDF1380Kb id114

[8] Lombardi P., Giordano S. (2012). Evaluating the european smart cities visions of the future, International Journal of the Analytic Hierarchy Process, Vol. 4, No. 1. DOI: 10.13033/ijahp.v4i1.108

[9] Giaccone A., Lascari G., Peri G., Rizzo G. (2016). An ex-post criticism, based on stakeholders' preferences, of a residential sector's energy master plan: the case study of the Sicilian region, Energy Efficiency, Vol. 10, No. 1, pp. 129-149.

[10] Torabi Moghadam S., Delmastro C., Lombardi P., Corgnati S.P. (2016). Towards a new integrated spatial decision support system in Urban context, Procediasocial \& Behavioral Sciences, Vol. 223, pp. 974-981. ISSN 1877-0428. DOI: $\underline{10.1016 / j . s b s p r o .2016 .05 .334}$

[11] Zhou P., Ang B.W., Poh K.L. (2006). Decision analysis in energy and environmental modeling: An update, Energy, Vol. 31, No. 14, pp. 2604-2621. DOI: 10.1016/j.energy.2005.10.023

[12] Catrinu M.D. (2006). Decision Aid for Planning Local Energy Systems, Application of Multi-Criteria Decision Analysis, Ph.D., Department of Electrical Power Engineering, Norwegian University of Science and Technology, Trondheim, Norway.

[13] Hobbs B.F., Horn G.T.F. (1996). Building public confidence in energy planning: a multimethod $\mathrm{MCDM} \backslash$ napproach to demand management at $\mathrm{BC}$ gas, 1996 International Symposium on Technology and Society Technical Expertise and Public Decisions. Proceedings, Vol. 25, No. 3, pp. 357-375. DOI: https://doi.org/10.1016/S0301-4215(97)00025-6

[14] Wang J.J., Jing Y.Y., Zhang C.F., Zhao J.H. (2009). Review on multi-criteria decision analysis aid in sustainable energy decision-making, Renewable and Sustainable Energy Reviews, Vol. 13, No. 9, pp. 22632278. DOI: $10.1016 /$ j.rser.2009.06.021

[15] De Montis A., De Toro P., Droste-franke B., Omann I., Stagl S. (2000). Assessing the quality of different MCDA methods, Alternatives for environmental valuation, pp. 99-184.

[16] Roy B. (1985). Méthodologie multicritère d'aide à la décision. Economica, Paris.

[17] Jin J., Wei Y. (2008). Generalized intelligent assessment methods for complex systems and applications, Beijing: Science Press.

[18] Roy B. (1985). Méthodologie multicritère d'aide à la décision, Economica, Paris, pp. 424, ISBN 27-1780901-5

[19] Xu J., Wu W. (2006). Multiple attribute decision making theory and methods., Beijing: Tsinghua University Press.

[20] Brans J.P., Vincke P., Mareschal B. (1986). How to select and how to rank projects: The Promethee method, European Journal of Operational Research, Vol. 24, No. 2, pp. 228-238. DOI: 10.1016/03772217(86)90044-5

[21] Diakoulaki D., Karangelis F. (2007). Multi-criteria decision analysis and cost-benefit analysis of alternative scenarios for the power generation sector in Greece, Renewable and Sustainable Energy Reviews, Vol. 11, No. 4, pp. 716-727. DOI: 10.1016/i.rser.2005.06.007

[22] De Montis A., De Toro P., Droste-franke B., Omann I., Stagl S. (2000). Assessing the quality of different MCDA methods, Alternatives for environmental valuation, pp. 99-184.

[23] Albadvi A., Chaharsooghi S.K., Esfahanipour A. (2006). Decision making in stock trading: An application of PROMETHEE, European Journal of Operational Research, Vol. 177, No. 2, pp. 673-683. DOI: $\underline{10.1016 / j . e j o r .2005 .11 .022}$

[24] Seddiki M., Anouche K., Bennadji A., Boateng P. (2016). A multi-criteria group decision-making method for the thermal renovation of masonry buildings: The case of Algeria," Energy and Buildings, Vol. 129, pp. 471-483. DOI: 10.1016/j.enbuild.2016.08.023

[25] Torabi Moghadam S.,Delmastro C., Corgnati S.P., Lombardi P. (2017) . Urban energy planning procedure for sustainable development in the built environment: A review of available spatial approaches, Journal of Cleaner Production, Vol. 165, pp. 811-827. ISSN 0959-6526. DOI: 10.1016/j.jclepro.2017.07.142

[26] Lombardi P., Abastante F., Torabi Moghadam S., Toniolo J. (2017). Multicriteria spatial decision support systems for future Urban energy retrofitting scenarios, Sustainability, Vol. 9, No. 7, p. 1252, ISSN 2071-1050. DOI: $10.3390 /$ su9071252

[27] Genco A., Viggiano A., Rospi G., Cardinale N. Magi V. (2015). Dynamic modeling and simulation of buildings energy performance based on different climatic conditions, International journal of heat and technology, Vol. 33, No. 4, pp. 107-116. DOI: 10.18280/ijht.330414

[28] Belton V., Stewart T. (2002). The multiple criteria problem, multiple criteria decision analysis an 
integrated approach, springer US, pp. 13-33. DOI: 10.1007/978-1-4615-1495-4

[29] Delmastro C., Mutani G., Corgnati S.P. (2016). A supporting method for selecting cost-optimal energy retrofit policies for residential buildings at the urban scale, Energy Policy, Vol. 99, pp. 42-56. DOI: 10.1016/j.enpol.2016.09.051 